\title{
Utilization Of Iron-Containing Waste from Magnetic Concentration of Kursk Magnetic Anomaly's Oxidized Ferruginous Quartzites
}

\author{
I. S. Bersenev ${ }^{1}$, I. S. Vochmyakova ${ }^{1}$, I. G. Bormotova², R. I. Ismagilov³, M. N. \\ Naftal ${ }^{3}$, and Yu. G. Yaroshenko 4 \\ ${ }^{1}$ NPVP TOREX, Osnovinskaya Str. 8, Ekaterinburgr, 620049 Russia \\ ${ }^{2}$ Michailovsky GOK, Lenin Str. 21, Zheleznogorsk, Kursk Region, 307130 Russia \\ ${ }^{3}$ METALLOINVEST, Rublevskoye Highway 28, Moscow, 121609 Russia \\ ${ }^{4}$ Ural Federal University, Mira Str. 19, Ekaterinburg, 620002 Russia
}

\section{Abstract}

The paper studies the problem of utilization of oxidized ferruginous quartzites which are stored with overburden at the present time. The solution of the problem is restrained by absence of efficient technology for concentration and lumping of these ores. The results of studing and analyzing quartzite concentration methods have shown that floatation methods are the most efficient way of producing a

Corresponding Author: I. S. Bersenev; email: i.bersenev@torex-npvp.ru

Received: 6 June 2017 Accepted: 9 July 2017

Published: 24 August 2017

Publishing services provided by Knowledge E

(a) I. S. Bersenev et al. This article is distributed under the terms of the Creative

commons Attribution

License, which permits unrestricted use and redistribution provided that the original author and source are credited.

Selection and Selection and Peer-review under the responsibility of the Technogen Conference Committee.

\section{G OPEN ACCESS} high-quality iron-ore concentrate. The produced concentrate contained up to $67 \%$ of iron. When lumping concentrates of oxidized quartzites, the derived products, i.e. agglomerates and pellets, can significantly improve technical and economic parameters of blast-furnace smelting in terms of productivity and specific coke consumption. The use of oxidized ferruginous quartzites will reduce the man-caused impact on the environment, which is important for regions with a high concentration of industrial plants.

Keywords: ferruginous quartzites, concentration, floatation, lumping, sinter, pellets, quality parameters

\section{Introduction}

In Russia more than $50 \%$ of iron ores and iron-ore concentrates derived from these ores are mined in unique fields of the Kursk Magnetic Anomaly (KMA): Michailovskoe, Stoylenskoe, Levedinskoe, Stoylo-Lebedinskoe. The concentration technology at large mining and concentrating plants developing these fields is oriented at processing magnetite ores using magnetic separation methods. Relatively rich hematite ores with the iron content up to $56 \%$ (up to $20 \%$ of the total volume) is used as a sinter burden but the most part of oxidized ores is stored together with overburden. The negative result of this practice is a low degree of grade (iron) recovery from the ore and a necessity to withdraw large black earth areas from agricultural use (for storing oxidized 


\begin{tabular}{|c|c|c|c|c|c|}
\hline & Concentrate type & $\begin{array}{l}\text { Fraction } 0.045 \\
{[\%]}\end{array}$ & {$[\mathrm{mm}]$,} & $\mathrm{Fe}_{\text {tot' }},[\%]$ & $\mathrm{SiO}_{2},[\%]$ \\
\hline Sample 1 & Magnetite & 88.2 & & 65.7 & 7.97 \\
\hline Sample 2 & Hematite (OFQ) & 96.9 & & 66.9 & $2.75-4.70$ \\
\hline
\end{tabular}

TABLE 1: Characteristics of Concentrates.

quartzites). Therefore, the use of oxidized ferruginous quartzites (OFQ) in metallurgical technology is an urgent problem and its solution will promote the development of mining and concentrating industry. Thus, the extraction volume of oxidized quartzites in the Michaylovskoe field is more than $50 \mathrm{~m}$ tons per year with the average iron content of $38 \ldots 42 \%$ (magnetic iron is less than 16\%). Their involvement in production is a long-range problem aimed at increasing efficiency of raw material processing $\left[1,4^{-}\right.$ 8]. Its solution is restrained by absence of efficient technologies for concentration and lumping of the materials of this kind, which has determined the selected objective of the paper [1-5]. The objective of the paper is an attempt to describe the main ways for solving the problem in question on the basis of earlier $[2,3,5]$ and new studies as well as to direct the way for further development of this scientific and technical area.

\section{Characteristics of Oxidized Quartzites}

The concentration processes of oxidized ferruginous quartzites were studied using various combinations of high-intensity magnetic separation and floatation (reverse cationic floatation with the use of column floatation machines). In the course of the works it has been determined that development of the flotation concentration technology is the most promising direction. Table 1 (Sample 2) shows a hematite concentrate which was received as a final product of OFQ concentration. For comparison, the table also shows the composition of the magnetite quartzite concentrate (Sample 2).

The data given in Table 1 show that the OFQ hematite concentrate made by the magnetic floatation concentration method is characterized by a higher content of $\mathrm{Fe}_{\text {tot }}$ (by $1.2 \%$ abs.) at a lower $\mathrm{SiO}_{2}$ content (by $3.27-5.22 \%$ abs.) as compared to the magnetite concentrate, which allows considering it as a promising raw material for ferrous metallurgy.

The microstructural analysis of the OFQ hematite concentrate has been made by the optical method (Axioscope A.1 CZ Binocular Polarized Light Microscope in reflected light) and using VEGA3 TESCAN Scanning Electron Microscope with preliminary preparation of samples in epoxy resin. The mineral composition has been determined by the $X$-ray phase method; the method of full-profile analysis (Rietveld method) was used for quantitative evaluation (mass \%). 


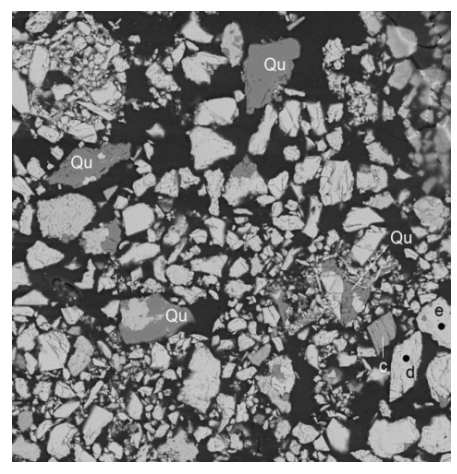

a

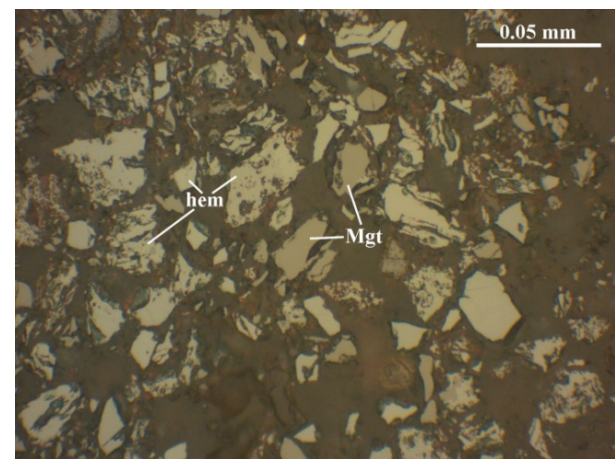

$\mathrm{b}$

Figure 1: Microstructural features of OFQ hematite concentrate: a - sample 1 (picture made by VEGA3 TESCAN Scanning Electron Microscope), b - sample 2 (picture made by Axioscope A.1 CZ Binocular Polarized Light Microscope in reflected light).

The mineralogical and microstructural analysis of the OFQ hematite concentrate has shown that the ore portion of the concentrate is represented by hematite (82\%) and magnetite (17\%) as well as by single grains of sulfides (pyrrhotine, pyrite). Figure 1 (a, b) shows the microstructure of different samples of the OFQ hematite concentrate. In the picture (Figure 1-a) hematite is represented by loose grains with sharp and irregular edges. The sample also contains magnetite $(d)$, quartz $\left(Q_{u}\right)$ and particles of soda ferrous silicate glass. Hematite is often banded by quartz. In the picture (Figure 1b) hematite (hem) is represented by cracked porous grains with irregular edges fused with magnetite $(\mathrm{Mgt})$ in some places.

Non-metallic minerals are represented by quartz, carbonate; rarely glass can be found. Carbonates were found both in fusion with hematite and free with thin quartz inclusions. In terms of composition, they are nonhomogeneous: from ferro-magnesian to purer ferruginous. Glass was found at the interface of hematite and carbonate and it is prevalent in the form of shards. The chemical analysis of the hematite concentrate given in Table 1 shows that its composition is characterized by higher $\mathrm{Fe}_{\text {tot }}$ (by 0.6...1.9\%) and lower $\mathrm{SiO}_{2}$ (by 3.68...5.33\%) as compared to the magnetite concentrate (unoxidized quartzites).

\section{Lumping and Blast Furnace Smelting of Oxidized Quartzite Concentrates}

\subsection{Sintering of the Oxidized Ferruginous Quartzite Concentrate}

Is characterized by a higher humidity of the burden as well as by higher fuel consumption; the latter is related to the absence of autothermal heat supply from magnetite 
oxidation [2]. Therefore, in order to produce agglomerate as strong as the agglomerate received with the use of the magnetite concentrate, it is necessary to increase the solid fuel consumption by $10 \%$ (relat.). When the magnetite concentrate is replaced with the oxidized ferruginous concentrate, the highest process parameters are achieved at the solid fuel consumption of $4.4 \%$ and burden humidity of $8.2 \%$. In this case, the working capacity of the sintering machine amounted to $74 \%$ of the base value (with magnetite burden, all other conditions being equal). Regarding the tumbler test results, quality of the agglomerate was as good as quality of the agglomerate made of the common magnetite concentrate of Michailovsky GOK. Regarding the iron content, it exceeded the agglomerate made of the common magnetite concentrate.

Estimation of breaking characteristics of agglomerates made of the hematite concentrate at their reduction has shown that the use of the oxidized ferruginous quartzite provides agglomerate with higher metallurgical properties [3]. Thus, the OFQ concentrate agglomerates are characterized by higher values of low-temperature strength $\left(\mathrm{LTD}_{+6.3}\right.$ is higher by $9.4 \ldots 14.3 \%, \mathrm{LTD}_{-3.15}$ is higher by $8 . . .12 \%$ and $\mathrm{LTD}_{-0.5}$ is lower by $2.3 . .3 .2 \%)$ as compared to magnetite agglomerates. The analysis of data on softening and melting temperatures shows that the softening/melting range gets narrower and softening temperature values get higher when the oxidized ferruginous concentrate is used. The higher values of metallurgical properties of the OFQ concentrate agglomerate establish a potential for higher efficiency of blast-furnace smelting, which is confirmed by the results of mathematical modelling of the blast-furnace process using a balance logic-statistical model. The process conditions of blast-furnace smelting at Ural Steel Integrated Works were used for modelling. The model results have shown that the OFQ concentrate agglomerate is capable of improving efficiency of blastfurnace smelting (as compared to magnetite concentrates) due to the reduced slag output. Moreover, due to the use of thermal and chemical potential of coke its specific consumption can be reduced by $4.80-10.15 \mathrm{~kg} / \mathrm{t}$ and the iron output of the blast furnace can be increased by $1.1-4.45 \%$.

\subsection{Use of the OFQ concentrate for pelletizing}

When studying the pelletizing process of the oxidized ferruginous quartzite concentrate, we have established that the pellets are characterized by the required values of mechanical properties regarding the compression strength amounting to $\sim 2.4-2.8$ $\mathrm{kg} / \mathrm{pel}$ and abrasion amounting to $\mathrm{b}_{+5}-95.4-96.8 \%, \mathrm{~b}_{-0.5}-3.2-4.3 \%$. The following options have been studied: use as a fuel only natural gas and composite fuel (natural gas for heating the induration furnace hearth and solid fuel for using in the sinter burden). It has been established that at the induration furnace capacity of 520 tons of fired 
pellets per hour without solid fuel in the burden the specific flow rate of natural gas increases by $10-19.6 \%$ as compared to hematite pellets with solid fuel. Consequently, production of hematite concentrate pellets on an industrial scale will require a site for solid fuel preparation, installation of the additional bin in the burden preparation area, etc. as well as cost-effectiveness analysis of different pelletizing options with the use of solid fuel or heat treatment of pellets in the induration furnace at a higher flow rate of natural gas. Mathematical modelling performed with consideration of the results obtained during pellet firing in the straight grate induration furnace of various capacity and data of the microstructural and mineralogical analysis has shown that uniform distribution of the compression strength throughout the height of the layer of fired pellets is possible with efficient distribution of process areas along the length of the straight grate induration furnace. In this case, it should be noted that the softening start temperature of hematite materials is generally higher by $50 . . .100^{\circ} \mathrm{C}$ and the melting range is wider (by $30 . . .80^{\circ} \mathrm{C}$ ) as compared to magnetite materials. Thus, the required strength of hematite ore pellets can be achieved only by increasing the maximum temperatures in the layer and by longer exposure of the material to high temperatures. The temperature at the layer/bed interface shall be higher by $50^{\circ} \mathrm{C}$ at a much bigger length of the induration furnace than it is during production of magnetite pellets.

Metallurgical properties of fired hematite concentrate pellets intended for metallization have been studied at Burghardt semi-industrial plant. The studies have showed that the oxidized ferruginous quartzite pellets are characterized by higher values of the sticking index and layer shrinkage which exceed the values of the magnetite concentrate pellets in 1.2 and 1.4 times respectively. Correction of the OFQ pellet burden is possible, for instance, by selection of basicity and also by coating pellets before reduction. In addition, the OFQ pellets have a higher degree of metallization (up to $95 \%$ ) exceeding the values typical of the magnetite pellets in the base option reduced at the semi-industrial plant.

The analysis of metallurgical properties of the pellets for blast-furnace production (Table 2) shows that the hematite concentrate pellets have a high quality. Thus, in terms of the LTD index the OFQ pellets are characterized by low breaking during reduction and, consequently, their use in the blast furnace will provide a high gas permeability of the burden column in the upper levels of the shaft. The OFQ pellets are also characterized by a higher softening start temperature and small softening/melting range, which intensifies blast-furnace smelting. 


\begin{tabular}{lllll} 
No. & Parameter & OFQ Pallets & Magnetite Pellets \\
1 & Reductibility, $\%$ & $62.0-65.0$ & $56.0-58.0$ \\
2 & Softening start temperature, ${ }^{\circ} \mathrm{C}$ & 1280 & 1190 \\
\hline 3 & Softening end temperature, ${ }^{\circ} \mathrm{C}$ & 1340 & 1270 \\
\hline 4 & Softening range, ${ }^{\circ} \mathrm{C}$ & 60 & 80 \\
\hline 5 & $\mathrm{LTD}_{+6.3,} \%$ & $98.0-98.8$ & $97.2-98.5$ \\
6 & $\mathrm{LTD}_{-3.15}, \%$ & $1.2-1.8$ & $1.2-2.4$ \\
7 & $\mathrm{LTD}_{-0.5} \%$ & $1.2-1.6$ & $1.5-2.1$
\end{tabular}

TABLE 2: Parameters of Michailovsky GOK's Concentrate Pellets intended for Blast-Furnace Process.

\section{Conclusions and Directions for Further Research}

1. Oxidized quartzites of the Michailovskoe field can be efficiently concentrated by flotation methods. The resulting high-quality iron-ore concentrate contains up to $67 \%$ of iron with $\mathrm{SiO}_{2}$ less than $3 \%$. The fraction prevailing in the concentrate is $0.045 \mathrm{~mm}$, more than $95 \%$.

2. When using the oxidized quartzite concentrate (instead of the magnetite concentrate) in the sintering process, it is necessary to consider a higher burden humidity, lower productivity of sintering machines and higher consumption of solid fuel for sintering. At the same time, the OFQ concentrate agglomerate has a higher quality due to a higher mass fraction of iron in the sinter and it also has high values of reductibility and strength during reduction. Replacement of the magnetite quartzite agglomerate with the oxidized quartzite agglomerate makes it possible to reduce the coke consumption by $4.8-10 \mathrm{~kg} / \mathrm{t}$ and increase the iron output up to $4 \%$.

3. At the production of pellets from oxidized ferruginous quartzites the specific heat consumption increases and this shall be taken into account during sintering technology development. These pellets are characterized by higher values of the sticking index and layer shrinkage which exceed the same values of the magnetite concentrate pellets in 1.2 and 1.4 times respectively. The breaking parameters of the OFQ pellets during reduction heat treatment as well as the softening/melting temperature range suggest wide opportunities for using the OFQ pellets in blast-furnace production. 
4. The obtained results enable to direct ways for solving the problem of utilization of iron-containing wastes from magnetic concentration, i.e. oxidized ferruginous quartzites. It is reasonable to direct further research to:

- Increasing efficiency of oxidized quartzite concentration by floatation;

- Selection of the optimum conditions for metallurgical processing of oxidized quartzites in the following cycles: sintering - blast-furnace smelting, pellet firing - blast-furnace smelting, pelletization - production of metallized products;

- Development of technical solutions for application of oxidized quartzite concentrates in existing technologies of iron-ore materials application.

The solution of these problems will increase application of useful components received from the mineral resources and reduce the man-caused impact on the environment, which is especially important for Russian regions with a high concentration of industrial plants.

\section{References}

[1] E. N. Shumskaya, O. Y. Poperechnikova, and S. P. Nagaeva, "Pilot assimilation of flotation technology for processing oxidized ferruginous quartzites," Eurasian Mining, vol. 2015, no. 1, pp. 21-24, 2015.

[2] 0. Y. Poperechnikova, E. N. Shumskaya, and S. P. Nagaeva, "Semi-industrial researches of flotation technology of hematite concentrate obtaining from oxidized ferruginous quartzites," Gornyi Zhurnal, vol. 2014, no. 11, pp. 40-43, 2014.

[3] V. I. Mulyavko, T. A. Oleynik, M. O. Oleynik, S. V. Mikhno, and V. I. Lyashenko, "Innovation technologies and machinery for separation of feebly magnetic ores," Obogashchenie Rud, no. 2, pp. 43-49, 2014.

[4] L. X. Yang and E. Matthews, "Oxidation and sintering of magnetite ore under oxidising conditions," ISIJ International, vol. 37, no. 9, pp. 854-861, 1997.

[5] Y. Y. Svetkina, "Intensification of concentration process through minerals vibroactivation," Naukovyi Visnyk Natsionalnoho Hirnychoho Universytetu, vol. 2, pp. 38-43, 2013.

[6] N. A. Shapovalov, L. H. Zagorodnyuk, and A. Y. Shchekina, "Enriched waste products of neon-ferrous oxidised quartzites- a mineral cement mixtures storage/accumulator," World Applied Sciences Journal, vol. 25, no. 3, pp. 529-535, 2013. 
[7] J. Wu, S. Wang, L. Graham, R. Parthasarathy, and B. Nguyen, "High solids concentration agitation for minerals process intensification," AIChE Journal, vol. 57, no. 9, pp. 2316-2324, 2011.

[8] R. H. Tabatabaei, D. R. Nagaraj, S. M. S. M. Vianna, T. J. Napier-Munn, and B. Gorain, "The effect of non-sulphide gangue minerals on the flotation of sulphide minerals from Carlin-type gold ores," Minerals Engineering, vol. 60, pp. 26-32, 2014. 